\title{
HODNOTY VE FILMOVÝCH POHÁDKÁCH
}

\author{
MOJMÍR SEDLÁČEK
}

\begin{abstract}
Abstrakt: Tento příspěvek vychází z diplomové práce vypracované autorem a obhájené v roce 2015. Zaměřuje se na filmové pohádky a jejich socializační roli při předávání hodnot. Právě pohádky jsou totiž častým nositelem hodnot a jejich prostřednictvím se děti učí rozlišovat různé způsoby chování a vztahování ke světu. Film jakožto médium je velmi populární a filmové pohádky jsou tudíž velmi sledované; jejich důležitost pro rozvoj dětí a osvojení si základních hodnot by proto měla být prozkoumána.

Vlastní empirický výzkum spočívá v obsahové analýze šestice vybraných českých (potažmo československých) pohádek a kódování situací, jež jsou hodnotově výrazné. Na základě těchto dat je možné vysledovat trendy v pojetí hodnot např́íc různými pohádkami. Kupříkladu starší pohádky jsou hodnotově výraznější a pro dětského diváka tudíž výchovnější, zatímco ty novější se spíše orientují na zábavnost a fúzi žánrů.
\end{abstract}

Klíčová slova: pohádky; hodnoty; film; média; socializace; vývojová psychologie; Česká republika

\section{Values in fairy tale movies}

Abstract: This paper is based on the thesis made by the author himself and defended in 2015. It focuses on fairy tale movies and their socializing role in the transfer of values. Fairy tales often contain values and learn children to distinguish different ways of behavior and relating to the world. Film as a medium is very popular and fairy tale movies are therefore highly watched; their importance for the children development and the adoption of basic values should therefore be explored.

The empirical research consists of a content analysis of six selected Czech (and Czechoslovak) fairy tales and the coding of situations that are worthwhile in terms of values. Based on these data, it is possible to identify trends in the concept of values across different fairy tales. For example, older fairy tales are more distinctive in values and therefore more educational for children while the newer ones tend to focus on entertainment and fusion of genres.

Keywords: fairy tale; values; film; media; socialization; developmental psychology; Czech Republic

https://doi.org/10.14712/23366486.2020.3

\section{Úvod}

Tento př́íspěvek vychází z diplomové práce obhájené v roce 2015 (Sedláček, 2015) a pojednává o pojetí hodnot ve filmových pohádkách. Pohádky jakožto zdroj dětských představ o světě byly již podrobeny mnohému zkoumání, to se však týká především 
pohádek literárních; filmové tvorbě, jakkoli důležité a mezi dětskými diváky populární, se dostalo výrazně menší pozornosti v celosvětovém měřítku, v tuzemských podmínkách je rozdíl ještě výraznější. Tato práce se proto zaměřuje na psychologický koncept hodnot, jenž je v pohádkách téměř vždy netriviálně zahrnut a při správném využití umožňuje dítěti vytváření základních hodnotových orientací, podstatný pro celý následující život.

$\mathrm{V}$ přehledové části jsou stručně probrány některé koncepty hodnot, s nimiž je následně dále pracováno. Rovněž jsou zmíněny př́stupy, jak média (a především film) mohou předávat sdělení dětskému publiku. A samozřjmě nejsou opomenuty ani vybrané koncepty pohádek, jež s naší prací bezprostředně souvisejí.

Výzkumná studie spočívá v obsahové analýze šestice vybraných českých a československých filmových pohádek a jejich následném rozboru z hlediska zvoleného pojetí hodnot.

\section{Teoretická východiska}

Témata hodnot, médií a pohádek jsou natolik široká, že pro účely tohoto článku je nutné je výrazně zúžit. $Z$ toho důvodu představíme jen několik základních konceptů pro každé ze tři sledovaných témat, které se navíc váží k dále rozpracovanému výzkumu.

\subsection{HODNOTY}

Řada definic pojmu „hodnota“ se shoduje na tom, že se jedná o individuální kategorii, jež je v průběhu lidského života poměrně stabilní a určuje směřování našich činů (Cakirpaloglu, 2009; Homola, 1972; Janoušek, Slaměník, 2008). Hodnoty se navíc netýkají čistě psychologické sféry, nýbrž přesahují i do filosofie, ekonomie a především sociologie, což nás bude pro účely sledování mediálních vlivů zajímat nejvíce.

Většina hodnotových koncepcí popisuje různě detailní hierarchie, v nichž se jednotlivé hodnoty naplňují; od nejnižších, fyziologických, tak jedinec postupuje až k těm nejvyšším, znázorňujícím například estetické ideály. Potřeba bezpečí a potravy je proto silnějším a zásadnějším motivem nežli honba za vznešenými myšlenkami přesahujícími život jedince. Jenže je tomu opravdu tak?

V tématu funkcí hodnot panují dlouhodobě určité spory. Již Maslow (1943) hovořil o funkční autonomii potřeb, tedy že načrtnutá hierarchie neplatí vždy, ale jakmile jednou došlo k naplnění vyšší potřeby, tato již může fungovat do značné míry nezávisle na potřebách nižších. V souladu s tím Smékal (2002) popisuje cíle, jejichž dosažení může být nakonec podstatnější nežli naplnění hierarchicky nižších potřeb. O poznání méně idealistický přístup však zastává kupř́ikladu Nakonečný (2004), podle něhož člověk spíše obětuje dosažení ideálu, pokud mu hrozí bezprostřední nebezpečí.

Nejednotnost a teoretičnost psychologických konceptů hodnot se pokusili překonat svými sociologickými studiemi Potůček (2002) či Prudký a kol. (2009). Jejich analýzy sledovaly vývoj tématu na přelomu milénia v českém i celoevropském kontextu. Z Potůčkových zjištění plyne jednak to, že tuzemské porevoluční liberální společnosti chybí jednoznačná hodnotová orientace. Aby také ne, změna režimu ve výrazně sekularizované společnosti k silnému zmatení hodnot vést snad i musí. Rostoucí trendy se projevily 
především v oblastech egoismu a hédonismu, což s příklonem ke konzumnímu a individualistickému způsobu života úzce souvisí.

Ještě poslední, ale o to důležitější jméno musíme v této souvislosti zmínit. Polsko-americký sociální psycholog Rokeach totiž už na přelomu 60. a 70. let přišel s nástrojem na měření hodnot, který obsahoval dvě kategorie: terminální a instrumentální hodnoty. V každé se nacházelo 18 položek, přičemž terminální hodnoty představovaly cílové stavy, jichž různí lidé mohou chtít dosáhnout, zatímco instrumentální hodnoty jsou prostředky, jak se k těmto cílům přiblížit. Do první skupiny patří třeba pohodlný život, opravdová láska, přátelství, rovnost, svoboda, sebeúcta, moudrost apod., ve druhé kategorii se nacházejí ctižádostivost, odvaha, odpovědnost, sebeovládání, nezávislost, shovívavost atd. Pomocí seřazení těchto hodnot je možné vysledovat žebříček priorit daného člověka, s čímž bylo výzkumně v následujících dekádách hojně pracováno. Jednak díky jednoduchosti takové metody, zároveň i díky univerzální pochopitelnosti daných hodnot. Tak mohl Rokeach vytvořit srovnávací data např́íč řadou zemí (především evropských a USA), stejně jako mezi různými skupinami obyvatel.

Na tyto poznatky následně navázala celá řada dalších autorů, nejvýznamněji Schwartz. Ten se snažil využít hodnot jakožto měřítek společnosti - prostředku, kterak porozumět širším jevům, jelikož zastáváním určitých hodnot jedinec nedává najevo pouze své osobní postoje, nýbrž se i podílí na formování postojů svého okolí (Prudký et al., 2009).

Ale ještě zmiňme několik poznámek k Rokeachovi, jehož teorie inspirovala i tento výzkum. Jeho pojetí hodnot zdůrazňuje individualitu každého hodnotového systému všichni si musíme najít svůj pohled na svět pro to, abychom mohli žít spokojený a naplněný život. Jestliže se toto podaří co nejvíce jedincům, bude profitovat i společnost. Kognitivní, behaviorální a afektivní složky, z nichž se podle Rokeache hodnoty skládají, evokují podobnost s psychologickým konceptem postojů. Sám Rokeach však považoval hodnoty za elementárnější a hlubší, díky neopomenutelnému obsahu motivace navíc podle něj hodnoty v podstatě předcházejí postojům (Rokeach, 1968).

\subsection{MEDIÁLNÍ PŮSOBENÍ}

Témata hodnot a působení mediálních obsahů (v našem př́padě pohádek) se protínají $\mathrm{v}$ rámci socializace. Tento proces zahrnuje aktivitu socializačních činitelů, kteří prostřednictvím různých mechanismů předávají obsahy (Sollárová, 2008). Jedná se o celoživotní proces, je však nasnadě, že nejvýrazněji se do jedince ,zapisují“ informace, jež přijme v prvních letech života, potažmo celém dětství. Na jejich základě se následně vytvářejí hodnotové hierarchie, jež bývají poměrně stabilní (Cakirpaloglu, 2009). Můžeme zde přitom vysledovat rozpor mezi společností, jež se snaží jedinci zvnitřnit konformitu, a samotným dítětem, které si testováním hranic pokouší udržet co největší nezávislost a individualitu. Jedná se tedy o oboustranně působící proces - dítě si do určité míry vybírá, jaké podněty zahrne do svých struktur a jaké nepřijme (Prudký et al., 2009). Psycholog Giles (2012) navíc doplňuje, že děti už v poměrně nízkém věku dokáží rozlišit mezi animovaným a hraným filmem, realistickým a zcela fiktivním obsahem. Zatímco se tedy mnoho výzkumných snah věnovalo především vlivu násilné tvorby na psychiku dětského diváka, je nutno si uvědomit, že i dětské publikum dokáže uchopit také výrazně komplikovanější a neprvoplánovější obsahy (Giles, 2012). 
Už Pondělíček (1964) psal o tom, že filmy jsou nejčastěji sledovány ve dvojicích, případně i větších skupinách. Tenkrát měl samozřejmě na mysli především návštěvu kin, ovšem tento př́stup $\mathrm{k}$ audiovizuálním dílům můžeme sledovat i dnes; obzvláště děti se na televize leckdy dívají i s rodiči, čímž dochází vedle přenosu informací z masového média i k naplnění jisté sociální funkce.

Tentýž autor psal i o tom, že dětský divák je přístupnější vnějším vlivům, které následně mohou jeho osobnost formovat výrazněji nežli u dospělých. To odpovídá dříve zmíněným tvrzením, že socializační funkce médií se zdaleka nejvýrazněji projevuje u dětí. Ačkoli tedy mediální sféra (a filmy konkrétně) bývá stále ve výčtu socializačních činitelů odsouvána až na okraj zájmu, měli bychom mít na paměti, že ačkoli se nejedná o socializaci záměrnou, její vliv je neopomenutelný. Což mimochodem ukázalo i slavné dílo A. Bandury zabývající se observačním učením. To vyzdvihuje pozorování jako metodu, kterou děti poznávají svět, a vysledované vzorce chování následně samy testují (Bandura, 1971).

Zde je však důležitá úloha dospělého, nejčastěji rodiče. V souladu s Vygotského (2004) zónou proximálního vývoje je dospělý důležitým článkem ve zpracování informací, které si dítě může z dané situace odnést. Pomoc ze strany dospělého s interpretací či zdůrazněním klíčových prvků (nejen) pohádkových děl může vést k rychlejšímu a komplexnějšímu porozumění složitějším prvkům.

\subsection{POHÁDKY}

Jak bylo naznačeno, právě pohádky jsou způsobem, kterým se děti mohou dozvědět o světu informace, jež není možné aktuálně zažít na vlastní kůži. Nejtradičnější skupina těchto děl - kouzelné pohádky - jsou zcela očividně smyšlené a nabízejí konzumentovi obsahu zjevně nereálný příběh. Především tím se liší od ostatních fantaskních žánrů, jež také mohou mít obsah hýřící nadpřirozenými jevy, avšak snaží se vytvořit iluzi realističnosti; to se týká kupř́kladu mýtů. Pohádka je však zřetelně nereálná, ačkoli její vztah ke skutečnému světu je rovněž nepopiratelný (Sirovátka, 1998).

Snad v žádném díle zabývajícím se interpretací pohádek nechybí jméno C. G. Junga, který především svým konceptem archetypů pomohl vytvoření interpretačního rámce, jejž využilo obrovské množství jeho následovníků. Archetypy představují základní nástroje vyprávění, které jsou mezigeneračně předávané, čímž je dosahováno jejich dlouhodobé srozumitelnosti (Franz, 2011). Bettelheim (2000) zmiňuje, že zatímco mýty či tradiční náboženské př́íběhy napomáhají porozumění okolního světa, pohádky slouží spíše k pochopení jedince samého. Jejich hrdinou totiž bývá obyčejný chlapec i dívka bez zvláštních schopností, je proto jednoduchém se s ní(m) ztotožnit a vzít si z řešení problému př́klad.

Důležitost pohádek pro vývoj dítěte je ukázána především při jejich interpretaci jakožto alegorii psychických procesů. Během dětství je totiž potřeba vyřešit spoustu problémů a čelit velkému množství změn, jež jsou s jednotlivými vývojovými obdobími spojeny. Hrdinové pohádek pomáhají leckteré takové procesy uchopit a naznačit důležitost kladně proběhlé změny. Pohádkové příběhy, jakkoli se mohou jevit vzdálené a odtržené od naší př́itomnosti, se tak symbolicky vztahují k lidské podstatě. Dítě či dospívající člověk díky nim může nejen leckterá témata pojmenovat, uchopit, nýbrž ideálně i objevit nástroje, kterak jim ve skutečném životě čelit (Mitchell, 2010). Pokud si vezmeme třeba Červenou Karkulku, Šípkovou Růženku, Popelku či Sněhurku, všechny tyto ženské 
hrdinky se nacházejí v jiném věku a čelí odlišným problémům, adekvátním jejich vývojové fázi (Bahbouh, 2013). Už předškolní děti přitom dokáží reagovat na různé pohádky různým způsobem; dokáží tak určit, které jsou pro ně vhodné a které jim v daném věku nic neřeknou (Bettelheim, 2000).

\section{Empirický výzkum}

Ve vlastním výzkumu jsme se pokusili témata popsaná v předchozí části propojit. Oblasti hodnot, pohádek a mediálních sdělení se kombinují ve filmových pohádkách, které představují důležitého zástupce socializačních činitelů, jenž je přitom ve výzkumných aktivitách zastoupen relativně málo. Analýza pohádkových filmů může napomoci definovat hodnoty, jež se v nich nejčastěji vyskytují, stejně jako doporučení, které konkrétní tituly jsou pro výchovné působení na děti nejvhodnější.

\subsection{CÍLE VÝZKUMU}

Filmy není možné zkoumat pouze izolovaně, nýbrž nám jejich povaha může naznačit i kinematografické trendy ve vztahu $\mathrm{k}$ hodnotám. Jak se kupř́íkladu v průběhu času proměňuje zastoupení hodnot $\mathrm{v}$ pohádkách? Vzhledem $\mathrm{k}$ možnému velmi širokému záběru se nebudeme pokoušet o zhodnocení děl ve vztahu k celospolečenským jevům, taková analýza by př́slušela spiše filmově-vědním oborům. $Z$ psychologického rozměru nás zajímá vhodnost výběru pohádek pro dítě za účelem předání hodnot.

Právě filmové pohádky jsou přitom k předání hodnot ideální, nebot' kombinují generacemi osvědčené archetypální zákonitosti s atraktivitou audiovizuálních děl; výsledek tak může dítě pobavit i poučit, což je z výchovného hlediska ideální kombinace. Zmíněné výzkumy hodnot (např. Potůček, 2002; Prudký et al., 2009) ukazují i na relativně malém časovém úseku dvou dekád znatelný posun v hodnotách společnosti. Je proto nasnadě, že obdobné trendy bude možné vysledovat i napríč uměleckými díly, a v delším časovém úseku obzvláště.

\subsection{VÝZKUMNÉ OTÁZKY}

Cílem bylo zmapovat část světa filmových pohádek, jemuž nebyla věnována obdobná výzkumná pozornost jako literárním pohádkám. $Z$ toho plyne kvalitativní výzkum s kvantitativními prvky zpracování dat. Formulovali jsme šest výzkumných problémů, jejichž předpoklady jsme zkoumali.

Výzkumný problém 1: Mění se v průběhu času celkový počet vyjádřených hodnotových projevi̊ v pohádkách?

Předpoklad: Počet zaznamenaných projevů hodnot je mezi zkoumanými pohádkami rozdílný.

Výzkumný problém 2: Mění se v průběhu času nejčastěji vyjadřované hodnoty v pohádkách?

Předpoklad: Nejčastěji vyjadřované hodnoty jsou v každé sledované pohádce odlišné. 
Výzkumný problém 3: Jsou typické pohádkové postavy napříč pohádkami shodné z hlediska hodnot, jež vyjadřují?

Předpoklad: Typické pohádkové postavy jsou z hlediska vyjadřovaných hodnot stejné.

Výzkumný problém 4: Jak jsou reflektovány kladné a záporné projevy hodnot?

Předpoklad: Kladných projevů hodnot bude více nežli těch záporných. Tyto kladné projevy hodnot budou také častěji a spíše kladně hodnoceny i ostatními postavami.

Výzkumný problém 5: Jsou hodnoty zobrazovány rovnoměrně během celé stopáže filmu? Předpoklad: Hodnotové projevy nejsou rovnoměrně rozděleny napříč celou stopáží filmu.

Výzkumný problém 6: Jsou projevy hodnot ve filmových pohádkách vyjadřovány spíše explicitně, nebo implicitně?

Předpoklad: Mezi zaznamenanými projevy hodnot převažují explicitní vyjádření nad implicitními.

\subsection{STRUČNÁ CHARAKTERISTIKA SOUBORU POHÁDEK}

Co se týče výběru pohádek, rozhodli jsme se pro zahrnutí celkem šesti pohádek z československé a české produkce. Regionální vymezení souvisí se zaměřením na českou společnost, její hodnoty a omezení vlivu odlišné kultury a mentality, jež se v dílech celého světa bezesporu projevují. Na základě Česko-Slovenské filmové databáze (www.csfd.cz), největší české databáze audiovizuálních děl, došlo k vybrání nejpopulárnějších (tedy nejvíce hodnocených) filmů z každé dekády od 50. let minulého století až do roku 2010. Starší snímky nejsou dostatečně známé a u novějších je metrika oblíbenosti kvůli nedokončené dekádě nevhodná. Popularita odráží penetraci díla ve společnosti, lze totiž předpokládat, že nejoblíbenější díla mají i největší ohlas a ovlivní největší množství lidí. A konečně, výběr jednoho snímku z každé dekády umožňuje sledovat trendy např́íč časem, tedy jak se kvalita i kvantita zobrazených hodnot projevily v nejtypičtějších dílech své doby.

Do výsledného souboru tedy byly zahrnuty pohádky Byl jednou jeden král (1954, režie Bořivoj Zeman), Š́leně smutná princezna (1968, režie Bořivoj Zeman), Tři ořiššy pro Popelku (1973, režie Václav Vorlíček), S čerty nejsou žerty (1984, režie Hynek Bočan), Princezna ze mlejna (1994, režie Zdeněk Troška) a Anděl Páně (2005, režie Jiř́i Strach).

\subsection{METODY A POSTUPY ANALÝZY DAT}

Jak bylo naznačeno v první části, pro účely tohoto výzkumu posloužila škála cílových (terminálních) hodnot Rokeache (1973). Ta definuje 18 možných hodnot, vyjadřujících různé směry lidského snažení a ve své komplexitě pokrývající motivaci a cíle většiny postav filmových i pohádkových děl. Na rozdíl od jiných hodnotových konceptů jsou navíc tyto položky poměrně jasně definované a uchopitelné, snižuje se tedy riziko vágnosti a abstrakce. Konkrétně se tedy jedná o následující hodnoty: pohodlný život (život v bohatství), vzrušující život (život plný stimulů a aktivity), dosažení výkonu (trvalý príinos), mír ve světě (bez válek a konfliktů), svět krásy (krása prírody a umění), rovnost (bratrství, rovné př́ležitosti pro všechny), bezpečí rodiny (péče o milované osoby), svoboda (nezávislost, svoboda volby), štěstí (spokojenost), vnitřní harmonie a soulad (osvobození 
od vnitřních konfliktů), zralá láska (sexuální a duchovní intimita), blaho národa (bezpečí a ochrana před útokem), potěšení (př́ijemný a poklidný život), spasení (věčný život), sebeúcta (hrdost), společenské uznání (respekt, obdiv), opravdové kamarádství (blízké př́telství), moudrost (zralé porozumění životu).

Samotnou metodou, jak tyto hodnoty zkoumat, byla obsahová analýza. Ta sama o sobě zahrnuje pestrou škálu práce s daty, a to jak kvalitativního, tak kvantitativního charakteru. Při výběru vhodného postupu jsme vycházeli ze dvou dělení obsahové analýzy, jak je navrhuje Plichtová (1996): deskriptivní př́stup předkládá kategorizaci na základě sesbíraných dat, tedy ex post, zatímco u teoretického prŕstupu má výzkumník předem stanovené kategorie a sbíraná data $\mathrm{k}$ nim přiřazuje. Druhým dělením spočívá ve sledování manifestních, tedy explicitních a jasně kvantifikovatelných významů, nebo zahrnutí i těch latentních, jež jsou závislé na interpretaci výzkumníka, a tedy kvalitativního charakteru. Pro účely této práce jsme zvolili interpretativní prístup, sledující i latentní významy, a pro kvantitativní zpracování dat teoretickou rovinu, v níž byly kategorie určené před započetím analýzy.

Konkrétní zpracování dat probíhalo na základě sledování filmů a kódování pozorovaných výjevů podle toho, zdali se jednalo o zachycení situace, postoje či hodnoty. Postavy totiž mohou leckdy jednat jen na základě situace, kdy jedna akce vyvolává reakci, leč z hlediska hodnot či zastávaných názorů zcela nezabarvenou. O úroveň výše se nachází jednání dle postojů, které pomáhají vykreslit daný charakter např́klad občasným lhaním takové chování nám postavu sice přibližuje, něco o ní vypovídá, avšak nesvědčí o hodnotové orientaci. To se týká až třetí skupiny, kde se prostřednictvím chování či promluv manifestuje př́klon k určité hodnotě podle Rokeachova (1973) výčtu. Právě tato kategorie nás zajímá, předchozí dvě jsou totiž důležité pro vyprávění př́iběhu a jeho kontinuitu, avšak nevyjadřují hodnoty se socializačním podtextem.

\subsection{VÝSLEDKY}

Na základě popsané metody proběhl sběr dat, tedy kódování hodnotových projevů ve všech šesti pohádkách. $V$ důsledku je tak možné odpovědět na výzkumné otázky následovně.

Výzkumný problém 1: Mění se v průběhu času celkový počet vyjádřených hodnotových projevů v pohádkách?

Tabulka 1 Počet hodnot v jednotlivých pohádkách

\begin{tabular}{|l|l|l|}
\hline Název pohádky & Počet hodnotových projevů & Počet unikátních hodnot \\
\hline Byl jednou jeden král & 27 & 12 \\
\hline Śíleně smutná princezna & 17 & 12 \\
\hline Tři oříšky pro Popelku & 26 & 10 \\
\hline S čerty nejsou žerty & 22 & 8 \\
\hline Princezna ze mlejna & 16 & 7 \\
\hline Anděl Páně & 16 & 8 \\
\hline
\end{tabular}

Rozdíly v množství vyjádřených unikátních hodnot i veškerých hodnotových projevů jsou v rámci vzorku významné, můžeme tedy potvrdit předpoklad. Počet hodnot ve 
sledovaných filmech se mění, a to tak, že o čím novější dílo se jedná, tím méně hodnotových vyjádření obsahuje.

Výzkumný problém 2: Mění se v průběhu času nejčastěji vyjadřované hodnoty $\mathrm{v}$ pohádkách?

Tabulka 2 Nejčastěji zaznamenané hodnoty

\begin{tabular}{|l|l|}
\hline Název pohádky & Nejčastěji vyjadřované hodnoty \\
\hline Byl jednou jeden král & sebeúcta, moudrost \\
\hline Š́leně smutná princezna & - \\
\hline Tři ořǐšky pro Popelku & svoboda, společenské uznání, opravdové kamarádství \\
\hline S čerty nejsou žerty & pohodlný život, rovnost, láska \\
\hline Princezna ze mlejna & láska \\
\hline Anděl Páně & rovnost \\
\hline
\end{tabular}

I zde dochází k potvrzení předpokladu, totiž že např́č sledovanými pohádkami se nejčastější hodnoty od sebe odlišují. Ukazuje se, že každá pohádka je zaměřena na značně odlišné sdělení. V prŕípadě Š́leně smutné princezny bylo naměřeno velké množství různých hodnot, žádná však nebyla zastoupena dostatečně často, aby bylo možné určit převažující prvky.

Výzkumný problém 3: Jsou typické pohádkové postavy např́č pohádkami shodné z hlediska hodnot, jež vyjadřují?

Původní očekávání bylo, že mladí hrdinové (at’ se jedná o prince a princezny, či chudé služky a řemeslníky) budou vyjadřovat podobné hodnoty a stejně tak i postavy vládců (král, Bůh, Lucifer). Pouze u mladých dívek však bylo možno vyčíst jako určující rys hledání lásky; mladí muži i vládcové byli z hlediska hodnot velmi odlišní a jednoznačné směřování nemají.

Výzkumný problém 4: Jak jsou reflektovány kladné a záporné projevy hodnot?

V centru zájmu nebylo jen samotné vyjadřování hodnot ústředními postavami, ale i reakce, jakých se jim dostalo ze strany okolí. To totiž také určuje formativní účinek celé akce a tedy zdali ji divák vyhodnotí jako správnou, či nikoli. Ze 124 zakódovaných projevů hodnot došlo k nějaké formě reakce $72 \times$. Pozitivních hodnotových projevů bylo v souladu s očekáváním zakódováno výrazně více a stejně tak i pozitivních reakcí na ně, které postavu v daném chování podpořily.

Výzkumný problém 5: Jsou hodnoty zobrazovány rovnoměrně během celé stopáže filmu?

Za tímto účelem došlo k rozdělení stopáže do tř́i částí, převážně respektujících základní rozdělení př́běhu na expozici, rozvíjení zápletky a katarzi. Zdaleka největší množství hodnotových projevů (54) bylo zaznamenáno v prvních třetinách filmů, což odpovídá předpokladu, že především zpočátku děje je nutné představit postavy a jasně načrtnout 
jejich hodnotové rámce. Ve druhé i třetí třetině pak bylo hodnotových projevů vysledováno o poznání méně (36, respektive 34$)$. Z hlediska hodnot je tedy právě první třetina klíčová - tehdy jsou představeny figury a jejich hodnotové ukotvení. Následný děj pak ukazuje, jak je zastávání určitých hodnot odměňováno, či naopak trestáno.

Výzkumný problém 6: Jsou projevy hodnot ve filmových pohádkách vyjadřovány spíše explicitně, nebo implicitně?

Hodnoty je možné vyjádřit jednoznačně, např́íklad verbální náklonností k dané kategorii, ale $\mathrm{k}$ témuž může docházet i prostřednictvím mimiky či gestikulace. Explicitních vyjádření bylo naměřeno výrazně více nežli implicitních (72 oproti 52), což odpovídá i výchovné a informativní povaze pohádky - jelikož se jedná o díla pro dětské publikum, je nanejvýš vhodné maximum sdělení podávat př́stupnou a snadno pochopitelnou formou.

\subsection{DISKUZE}

Co se týče další práce s výzkumnými tématy, můžeme navrhnout rozšíření vzorku i metod. Není nutné se omezovat pouze na filmové pohádky, nýbrž i jejich televizní variace či seriály by stály za výzkumnou pozornost. Nutno poznamenat, že kódování hodnotových projevů je do značné míry závislé na osobě výzkumníka, čímž může dojít k určitému zkreslení. To se týká především implicitních vyjádření, jež jsou hůře interpretovatelné, ale jistě by mohly rozpory nastat i v jiných oblastech. Pro další zkoumání by proto bylo vhodné zahrnout do analýzy větší množství výzkumníků, čímž by byl problém subjektivity značně omezen.

Nabízí se také otázka, pro koho jsou dané výsledky vlastně určeny? Na základě vývojových období dává největší smysl použití pro děti školního věku, tedy zhruba mezi šesti a patnácti lety. Tou dobou už děti jednak chápou delší a komplexnější příběhy, zároveň je možné s nimi uvažovat o jaksi abstraktních pojmech, jimiž hodnoty bezesporu jsou. Jednodušší př́běhy s jasným poselstvím jsou samožrejmě vhodné i pro menší děti, avšak využité filmové pohádky vyžadují více pozornosti a pochopení. Tomu samozřejmě může napomoci i rodič (či jiná důležitá osoba), která může chování postav komentovat a na leckdy subtilní náznaky hodnot upozorňovat. Obecně je samozřejmě nutné úlohu významného druhého nepodceňovat, a především v nižším věku dítěti s interpretací viděných obsahů pomoci. Právě možnost určitého zarámování prezentovaných filmových děl (či jakýchkoli jiných mediálních výstupů) se totiž ukazuje jako klíčová; rodiče či jiní přítomní dospělí tak mohou filmového média snadno využít k socializačním účelům.

\section{Závěr}

Tato studie se snažila proniknout do tématu, jež zatím bylo spíše na okraji zájmu. Navzdory rozsáhlé literatuře zabývající se analýzami literárních pohádek a obecně pohádek jakožto kulturního fenoménu, zaměření na filmové médium dosud tak časté nebylo. Přitom o jeho vlivu na dětského diváka nemůže být pochyb, nebot’ více než kdykoli dřív jsou děti od útlého věku mediálním obsahům vystaveny. 
Z obsahové analýzy šestice českých (potažmo československých) filmových pohádek vzešlo, že starší díla obsahovala větší množství hodnotově výrazného chování oproti těm novějším. Lze proto usoudit, že starší snímky jsou z hlediska předání hodnot a socializačních možností filmového média pro děti vhodnější. Tento závěr nemá nic společného se samotnou zábavností - nové pohádky mohou být pro děti stejně zajímavé, ovšem minimálně v námi sledovaných případech je patrné, že novější tvorba se zaměřuje spíše na žánrové přesahy (např́iklad do komedie či muzikálu) a nedrží se již pohádkových tradic tak striktně.

Sledovaný vzorek, ačkoli čítal pouze šest filmových děl, ukázal velkou rozmanitost mezi celkovým rozptylem hodnot i tím, co vyjadřují jednotlivé postavy. Lze proto usoudit, že filmové pohádky obsahují velké množství motivů, vhodných pro různé věkové kategorie i edukativní účely. Stálicí je však odsuzování špatného chování a naopak podpora toho správného, dobrého; v tomto ohledu tedy nedošlo k narušení tradičního obrazu, jež o pohádkách máme. Zároveň se tak potvrdil předpoklad, že současná filmová tvorba se od tradičních, hodnoty vytvářejících pohádkových zdrojů do značné míry odlišuje, a tak pro jednodušší předávání hodnot nutných k podpoře jistoty a orientovanosti ve světě je vhodnější využít starší tvorbu.

\section{LITERATURA}

Bahbouh, R. (2013). Bylo nebylo. [Vyhledáno 5. 10. 2018 na https://psychologie.cz/bylo-nebylo] Bandura, A. (1971). Social Learning Theory. New York City: General Learning Press.

Bettelheim, B. (2000). Za tajemstvím pohádek: proč a jak je číst v dnešni době. Praha: Lidové noviny.

Cakirpaloglu, P. (2009). Psychologie hodnot. Olomouc: Univerzita Palackého v Olomouci.

Franz, M. L. von (2011). Psychologický výklad pohádek: smysl pohádkových vyprávění podle jungovské archetypové psychologie. Praha: Portál.

Giles, D. (2012). Psychologie médií. Praha: Grada.

Homola, M. (1972). Motivace lidského chování. Praha: Státní pedagogické nakladatelství.

Janoušek, J., Slaměník, I. (2008). Sociální motivace. In J. Výrost, I. Slaměník (Eds.). Sociální psychologie (147-160). Praha: Grada.

Maslow, A. H. (1943). A Theory of Human Motivation. Psychological Review, (4), 370-396.

Mitchell, M. B. (2010). Learning about ourselves through fairy tales: their psychological value. Psychological Perspectives, (53), 15.

Nakonečný, M. (2004). Motivace lidského chování. Praha: Academia.

Plichtová, J. (1996). Obsahová analýza a jej možnosti využitia v psychológii. Československá psychologie, (4), 304-314.

Pondělíček, I. (1964). Psychologie ve vztahu k uměni, jmenovitě filmovému. Praha: Státní pedagogické nakladatelství.

Potůček, M. (2002). Průvodce krajinou priorit pro Českou republiku. Praha: Gutenberg.

Prudký, L. et al. (2009). Inventura hodnot: výsledky sociologických výzkumů hodnot ve společnosti České republiky. Praha: Academia.

Rokeach, M. (1968). A Theory of Organization and Change Within Value-Attitude Systems. Journal of social issues, (1), 13-33.

Rokeach, M. (1973). The Nature of Human Values. New York: The Free Press.

Smékal, V. (2002). Pozváni do psychologie osobnosti: člověk v zrcadle vědomí a jednání. Brno: Barrister \& Principal.

Sedláček, M. (2015). Hodnoty ve filmových pohádkách. Diplomová práce. Praha: FF UK.

Sollárová, E. (2008). Socializace. In: J. Výrost, I. Slaměník (Eds.). Sociální psychologie (49-68). Praha: Grada. 
Vygotskij, L. S. (2004). Psychologie myšleni a řeči. Praha: Portál.

Mgr. et Mgr. Mojmír Sedláček vystudoval psychologii na FF UK a mediální studia na FSV UK. V současnosti pracuje jako novinár a filmový kritik. Studuje doktorský program sociálni psychologie na FF UK a je frekventantem integrativního psychoterapeutického výcviku Instep.E-mail: sedlacek.mojmir@seznam.cz 